\title{
Pengaruh Pembayaran Non Tunai Sebagai Promosi Pada Masa Pandemi COVID 19 Terhadap Keputusan Pembelian di Sudut Pandang Kopi
}

\author{
Yudhiet Fajar Dewantara ${ }^{1}$, Surya Aldi ${ }^{2}$ \\ Program Studi Hospitality dan Pariwisata, Fakultas Ilmu Sosial Dan Humaniora, \\ Universitas Bunda Mulia Jakarta, Indonesia \\ Email : Ydewantara@bundamulia.ac.id
}

\begin{abstract}
Abstrak
Riset ini dilakukan karena adanya meningginya pemakaian pembayaran Non Tunai di era endemi Covid- 19 dibanding dengan pembayaran kas. Tujuan dari riset ini ialah untuk mengetahui dampak media Pembayaran Non Tunai di era endemi Covid- 19 kepada minat beli di Sudut Pandang Kopi. Prosedur riset memakai pendekatan kuantitatif kausal. Metode pengumpulan informasi dilakukan memakai angket sebesar 150 responden, serta hasil dari informasi angket itu hendak dianalisis oleh peneliti. Peneliti pula memakai informasi sekunder serta informasi primer seperti buku, jurnal, serta referensi berhubungan dalam mendukung riset ini. Alat analisa yang dipakai riset ini merupakan analisa keabsahan serta reliabilitas, uji asumsi klasik, Percobaan Hipotesis. Kesimpulan dari riset ini Pembayaran Non Tunai amatlah bepengaruh selaku alat promosi yang terdapat pada sudut pandang kopi. Anjuran riset hendaknya lebih banyak lagi buat alat pembayaran Non Tunai yang terkini, setelah itu membagikan gift pada pelangan regular.
\end{abstract}

Kata Kunci: Pembayaran Non Tunai, Promosi, Keputusan pembelian , Kopi

\begin{abstract}
This research was conducted because of the higher use of Non-cash payments in the Covid19 endemic era compared to cash payments. The purpose of this research is to determine the impact of Non-Cash Payment media in the Covid-19 endemic era on buying interest in Coffee Viewpoints. The research procedure uses a causal quantitative approach. The method of collecting information was conducted using a questionnaire of 150 respondents, and the results of the questionnaire information were to be analyzed by the researcher. Researchers also use secondary information and primary information such as books, journals, and related references to support this research. The analytical tools used in this research are validity and reliability analysis, classical assumption tests, and hypothesis experiments. The conclusion of this research is that Non-Cash Payments are very influential as a promotional tool found in the coffee perspective. More research suggestions should be made for the latest non-cash payment instruments, after that distribute gifts to regular customers.
\end{abstract}

Keywords: Non-cash payments, promotion, purchase decisions, coffee 


\section{PENDAHULUAN}

Persaingan dalam dunia bisnis kuliner semakin ketat, membuat para pengusaha berusaha mencari strategi yang paltepat untuk produknya. Pada era globalisasi telah muncul adanya perubahan paradigm lama dalam segala bidang salah satunya adalah bidang pemasaran . semakin tinggina tingkat persaingan di bisnis kuliner dan kondisi ketidakpastian memaksa penguasaha mencapai keunggulan bersaing (competitive advantage ) agar mampu memenangkan persaingan di bisnis kuliner. Food and beverage sendiri ialah kepentingan dasar untuk orang yang harus dipadati. Alhasil bidang usaha food and beverage ini jadi tren di indonesia dikala ini serta pula pelaku bidang usaha butuh mempraktikkan rancangan penjualan serta memperhatikan sikap pelanggan serta faktor- faktor yang pengaruhi minat belinya. Dalam sebagian tahun terakhir bidang usaha food and beverage lalu meningkat dengan ragam produk yang berbagai macam

Tabel 1. Pertumbuhan Industri Food \&

Beverage di Indonesia

\begin{tabular}{|c|c|c|c|c|c|c|c|c|}
\hline \multirow{2}{*}{} & \multicolumn{4}{|c|}{ year on year } & \multicolumn{4}{c|}{ Pertumbuhan Kumulatif ( c to } \\
\cline { 2 - 9 } & $\begin{array}{c}\mathrm{Q} 2 / 2 \\
\text { Industri }\end{array}$ & $\begin{array}{c}\mathrm{Q} 3 / 2 \\
018\end{array}$ & $\begin{array}{c}\mathrm{Q} 2 / 2 \\
019\end{array}$ & $\begin{array}{c}\mathrm{Q} 3 / 2 \\
019\end{array}$ & $\begin{array}{c}\mathrm{Q} 2 / 2 \\
018\end{array}$ & $\begin{array}{c}\mathrm{Q} 3 / 2 \\
018\end{array}$ & $\begin{array}{c}\mathrm{Q} 2 / 2 \\
019\end{array}$ & $\begin{array}{c}\mathrm{Q} 3 / 2 \\
019\end{array}$ \\
\hline $\begin{array}{c}\text { Industri } \\
\text { Makanan }\end{array}$ & 8.49 & 8.02 & 7.41 & 7.74 & 10.66 & 9.74 & 6.79 & 7.12 \\
\hline $\begin{array}{c}\text { Industri } \\
\text { Minuman }\end{array}$ & 13.23 & 10.06 & 22.52 & 23.69 & 9.93 & 9.97 & 22.74 & 23.06 \\
\hline
\end{tabular}

Sumber: Kemenperin (2019)

Salah satu industri food and beverage yang bertumbuh cepat dikala ini ialah Coffee shop. Coffee shop ialah suatu restoran yang mulanya sediakan tempat buat minum kopi serta teh dengan cara cepat, namun sebab kemajuan serta permohonan keinginan klien yang amat variatif hingga coffee shop telah banyak tersebar di bermacam tempat. Banyaknya coffee shop di wilayah jakarta dengan tempat yang menarik serta lezat untuk bebas membuat atensi pelanggan terus menjadi bertambah. Dan dengan diiringi oleh kemajuan teknologi yang dipakai oleh coffee shop semacam dalam pembayaran elektronik yang gampang serta kilat. Kemajuan teknologi yang terus menjadi mutahir membagikan banyak khasiat semacam fitur yang bisa mempermudah dalam melaksanakan bisnis pembayaran ataupun lazim diketahui dengan Financial technology. Financial technology ialah pertukaran uang tunai menjadi non- tunai dengan memakai aplikasi. Menurut Pribadiono, Hukum, Esa, Barat( 2016), berkata kalau Financial Technology ( Fintech) ialah kombinasi antara teknologi serta fitur finansial ataupun bisa pula dimaksud inovasi pada zona keuangan dengan gesekan teknologi modern.

Pembayaran elektronik ataupun epayment ialah bentuk pembayaran yang bisa mempermudah konsumen serta membagikan kenyamanan dalam melaksanakan bisnis pembayaran. Bagi Ming-Yen Teoh et al., ( 2013) Electronic payment dipakai pada dikala ini buat berbisnis jarak jauh semacam online shoping, bersamaan dengan terus menjadi bertumbuhnya pemakaian internet serta terus menjadi banyaknya e- commerce, hingga electronic payment merupakan pemecahan yang muncul buat mengambil alih perlengkapan bisnis pembayaran metode lama. Terdapat sebagian tipe yang bisa dipakai dalam pembayaran elektronik ialah digital cash ataupun e- cash, e- wallet, smart card. Tiap tipe pembayaran itu mempunyai metode bisnis yang berlainan sebab memiliki karakter, peranan, utilitas, dan kelebihan tiap- tiap. Sebagian contoh e- cash, e- wallet, dan smart card yang kerap dipakai oleh pelanggan ialah: Sakuku, Link Aja, Go- Pay, Grab- Pay, Ovo Cash, Shopee Pay, Mandiri e- cash, Dana. embayaran Non Tunai di Indonesia sendiri dianjurkan oleh penguasa serta Bank Indonesia sehubungan dengan terdapatnya endemi covid- 19. Covid- 19 ialah penyakit yang diakibatkan oleh virus corona serta penyebarannya lewat air liur, maka dianjurkan buat kurangi gesekan kepada permukaan barang serta wajah. Dengan terdapatnya pembayaran elektronik ini, hingga tingkatan penyebaran covid- 19 bisa menurun. Salah satu Coffee Shop yang memakai pembayaran elektronik ialah Sudut 
Pandang Kopi agen Pasar Terkini. Dengan sediakan pembayaran elektronik di Sudut Pandang Kopi agen Pasar Terkini hingga bisa tingkatkan atensi pelanggan buat membeli produk.

Pada pertengahan 2019 Sudut Pandang Kopi sudah meluaskan cabangnya di bermacam tempat di Jakarta ataupun luar Jakarta. Kemudian Sudut Pandang Kopi pula membuka franchise untuk yang ingin dengan preferensi paket yang ada. Menurunnya angka wisatawan dalam sesuatu subjek wisata, dapat diakibatkan dari bermacam perihal, ilustrasinya dapat diamati dari bidang sarana yang belum maksimum buat memenuhi keinginan wisatawan, pula dapat dari perspektif daya tarik di dalamnya yang tidak dirawat dengan cara teratur serta pula dapat diamati dari bidang promosi yang dipakai buat menarik wisatawan. Tetapi dalam perihal ini, peneliti mengetahui, terdapatnya aktivitas yang kurang maksimum dalam melaksanakan promosi buat menarik ketetapan pembelian buat membeli produk di sudut padang kopi. Bagi Tjiptono dalam Yofina Mulyati serta Miko Afrinata( 2018: 194) berkata kalau promosi merupakan seluruh aktivitas yang dimaksudkan buat mengantarkan ataupun mengkomunikasikan suatu produk pada pasar target, buat membagikan data mengenai keunggulan sesuatu produk. Berdasarkan dari definisi yang disampaikan, peneliti belum menemukan adanya kegiatan yang maksimal untuk menarik keputusan pembelian. Berikut terdapat gambar yang menunjukkan adanya kegiatan promosi yang dilakukan melalui media Instagram seperti gambar di bawah ini:

Gambar 1. Konten Kegiatan Promosi Susut Pandang Kopi Melalui Media Sosial

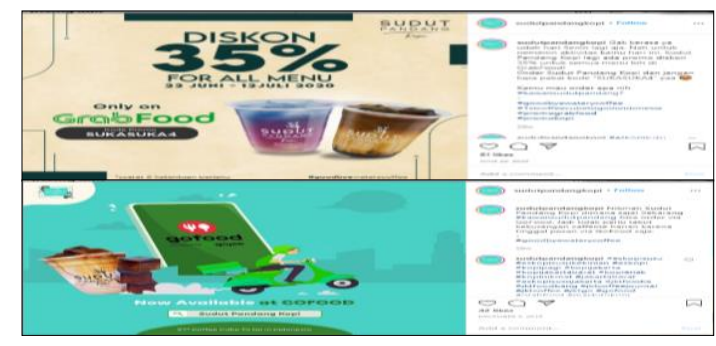

Sumber: Media Instagram Sudut Pandang Kopi

Gambar 2. Media Promosi Offline Melalui Banner di dalah Satu Outlet Sudut Pandang Kopi.

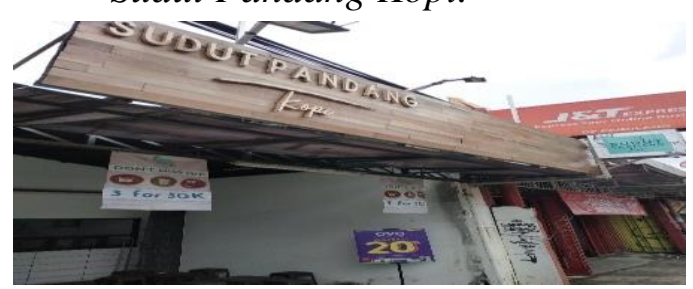

Sumber: Hasil Observasi Penulis 2020

Menurunnya angka data omset periode maret sampai april, bisa disebabkan dari berbagai hal, akan tetapi pada terdapat kenaikan kembali pada bulan berikutnya yakni bulan mei dan juni. Namun dalam hal ini, peneliti menyadari, adanya kegiatan yang kurang maksimal dalam melakukan promosi untuk menarik minat berkunjung.



Sumber: Salah satu Outlet Sudut

Pandang Kopi cabang Pasar Baru

Melihat perbandingan penjualan pembayaran Non Tunai dan pembayaran tunai di Sudut Pandang Kopi pada bulan Juli 2019 - Juni 2020, terjadi selisih harga yang signifikan antara transaksi pembayaran non tunai dan pembayaran tunai dimana pada Sudut Pandang Kopi, konsumen lebih sering 
menggunakan pembayaran non tunai dibandingkan dengan pembayaran tunai. Pembayaran elektronik yang dapat dilakukan di Sudut Pandang Kopi cabang yaitu menggunakan Ovo, Go-Pay, Shopee Pay, dan Dana. Dapat dilihat juga dari data di atas mamang melangalami penurunan data penjualan, berdasarkan itulah peneliti melakukan penelitian tersebut.

\section{METODOLOGI}

Penelitian ini dilaksanakan di Sudut Pandang Kopi. Pada penelitian ini penulis menggunakan metode penelitian kuantitatif dengan jenis penelitian asosiatif kausal. Dalam penelitian ini, jumlah populasi diambil dari data jumlah pengunjung yang pernah berkunjung di Sudut Pandang Kopi pada tahun 2020. Penulis menggunakan probability sampling dengan pendekatan simple random sampling. Di mana penulis akan memberikan peluang atau kesempatan yang sama bagi setiap anggota populasi untuk dipilih sebagai sampel. Menurut Sugiyono (2017), probability sampling merupakan metode pengumpulan sampel yang membagikan kesempatan yang serupa untuk tiap factor (bagian) populasi buat diseleksi jadi badan ilustrasi.. Dalam penelitian ini, penulis menggunakan teknik nonprobability sampling dengan jenis purposive sampling, dimana purposive sampling adalah teknik penentuan sampel dengan pertimbangan tertentu (Sugiyono, 2017). Dimana sampel yang di tentukan adalah yang sudah mengunjungi Sudut Pandang Kopi.

Teknik penelitian ini dilakukan oleh peneliti dikarenakan sampel yang dituju oleh peneliti hanya responden yang pernah melakukan pembelian makanan dan minuman di Sudut Pandang Kopi

Sampel dalam penelitian ini adalah kelompok umur 17 tahun sampai 65 tahun yaitu masa remaja akhir hingga masa lansia akhir karena peneliti yakin pada usia tersebut responden sudah sangat matang dan memiliki keseriusan dalam pengisian kuesioner, hal ini menanggulangi pengisian kuesioner yang kurang representatif.

Berikut merupakan tabel klasifikasi usia menurut Departemen Kesehatan Republik Indonesia (2009).

\section{Tabel 3. Tabel Klasifikasi Usia}

\begin{tabular}{|c|c|c|}
\hline No. & Masa & Usia \\
\hline 1. & Masa Balita & $0-5$ Tahun \\
\hline 2. & Masa Kanak-kanak & $6-11$ Tahun \\
\hline 3. & Masa Remaja Awal & $12-16$ Tahun \\
\hline 4. & Masa Remaja Akhir & $17-25$ Tahun \\
\hline 5. & Masa Dewasa Awal & $26-35$ Tahun \\
\hline 6. & Masa Dewasa Akhir & $36-45$ Tahun \\
\hline 7. & Masa Lansia Awal & $46-55$ Tahun \\
\hline 8. & Masa Lansia Akhir & $56-65$ Tahun \\
\hline 9. & Masa Manula & $65-$ Atas \\
\hline
\end{tabular}

Sumber: Departemen Kesehatan Republik Indonesia (2009)

Adapun salah satu penentuan jumlah sampel yang dikembangkan oleh Roscoe dalam Sugiyono (2015) adalah ukuran sampel yang layak dalam penelitian antara 30 sampai dengan 500. Menurut Hair, Joseph F. Jr. et al (2010) menyatakan bahwa jumlah sampel sebagai responden adalah 5 kali dari jumlah pertanyaan yang terdapat dalam kuesioner. Terdapat 1 variabel bebas yang memiliki 2 indikator dan 1 variabel terikat yang memiliki 4 dimensi, dan total pernyataan yang dibuat untuk penelitian ini berjumlah 18 pernyataan. Maka dari itu, jumlah minimal sampel dalam penelitian ini adalah 5 × $30=150$ responden dan dalam penelitian ini, peneliti akan mengambil sampel sebanyak 150 responden.

Dalam penelitian ini penulis menggunakan skala Likert, dimana menurut Siregar (2015) skala Likert merupakan skala yang dapat digunakan untuk mengukur sikap, pendapat dan persepsi seseorang tentang suatu obyek atau fenomena tertentu. Dengan menggunakan skala Likert, maka variabel yang akan diukur akan dijabarkan terlebih dahulu dari variabel menjadi dimensi, dari dimensi dijabarkan lagi menjadi indikator yang dapat diukur

Menurut Sugiyono (2017), pada penyusunan kuesioner yang menggunakan skala Likert yang merupakan skala untuk 
mengukur sikap, pendapat dan persepsi seseorang atau sekelompok orang tentang fenomena sosial. Dalam skala Likert, penulis menggunakan 4 kategori sebagai item pilihan, dimana masing-masing memiliki keterangan sendiri, yaitu :

1. Skor 4 mengidentifikasi Sangat Setuju (SS)

2. Skor 3 mengidentifikasi Setuju (S)

3. Skor 2 mengidentifikasi Tidak Setuju (TS)

4. Skor 1 mengidentifikasi Sangat Tidak Setuju (STS)

Maka, berdasarkan pengertian tersebut, dalam penelitian ini peneliti menggunakan Skala Likert dengan empat titik pilihan jawaban yang digunakan. Dalam penelitian ini menggunakan metode analisis statistic dengan bantuan Software Statistical Product and Service Solutions (SPSS) versi 25.0. Dimana pada penelitian ini akan menggunakan uji validitas, uji reliabilitas, uji asumsi klasik (uji normalitas, uji multikolinearitas, uji heteroskedastisitas dan uji autokorelasi), analisis regeresi linear berganda (uji-t parsial, uji $\mathrm{F}$ simultan, dan analisis koefisien korelasi dan determinasi). Dimana variabel ini akan diteliti dan diukur pada penelitian ini adalah variabel X1yaitu Pembayaran Non Tunai, X2 Promosi dan Y Keputusan Pembelian.

\section{HASIL DAN PEMBAHASAN}

Sudut Pandang Kopi berdiri sejak tahun 2017 dengan konsep 1st Coffee Cube To Go in Indonesia yaitu konsep dengan menggantikan es batu biasa menjadi kopi sehingga rasa kopi tidak berubah pada saat dibawa. Dengan hal ini apabila es batu yang terbuat dari kopi ini mencair maka rasa kopi pun akan semakin terasa dan tidak watery. Responden diambil dari pengunjung yang pernah mengunjungi Sudut Pandang Kopi. Dalam penelitian ini, peneliti tidak menentukan area wilayah maupun karakteristrik tertentu untuk menentukan responden yang diambil, karena responen yang diambil merupakan responden yang pernah berkunjung ke Sudut Pandang Kopi, tidak ada batasan wilayah tertentu maupun karakteristik tertentu dalam menentukan responden untuk dijadikan bahan penelitian. Total responden dalam penelitian ini adalah sebanyak 150 (seratus lima Puluh) responden, di mana responden ini merupakan pengunjung yang sudah pernah berkunjung ke Sudut Pandang Kopi

Pada bagian ini, peneliti menguraikan penjelasan mengenai hasil dari penyebaran kuesioner yang sudah di olah oleh peneliti untuk mengetahui pengaruh media pembayaran Non Tunai di masa pandemi covid-19 terhadap Keputusan Pembelian di sudut pandang kopi cabang pasar baru, khususnya pada kalangan umur dari 17 tahun ke atas menurut Departemen Kesehatan Republik Indonesia (2009). Subjek penelitian ini adalah kelompok usia remaja akhir dengan usia 17 tahun hingga kelompok usia manula yang sudah pernah membeli produk makanan dan minuman di Sudut Pandang Kopi. Peneliti menyebarkan kuesioner kepada 150 responden selama kurang dari 2 minggu dari tanggal 15 Desember 2020 hingga 30 Desember 2020. Data yang ditanyakan kepada responden adalah, pernah atau tidak pernah mengunjungi Sudut Pandang Kopi, Jenis kelamin, Usia, Pekerjaan, Pendapatan per bulan, Domisili, Frekuensi Membeli Kopi Dalam 1 Minggu, Frekuensi Berkunjung Ke Sudut Pandang Kopi,

Mengetahui Informasi mengenai Sudut Pandang Kopi. Dari 150 kuesioner yang digunakan diperoleh data atau profil responden sebagai berikut:

\section{a. Frekuensi Membeli Kopi Dalam Satu Minggu}

Berdasarkan hasil olah data dari hasil responden yang berkunjung untuk membeli kopi yaitu pengunjung yang sudah pernah berkunjung ke Susut Pandang Kopi sebanyak 150 responden maka dapat disimpulkan bahwa menurut hasil 1-2 kali dalam semingu sebanyak $58 \%$ sedangkan dari hasil konsumsi 3-4 kali dalam seminggu adalah 
$39 \%$ dan yang terakhir 5-7 kali dalam seminggu $3 \%$. maka dapat simpulkan dimana pada frekuensi 1-2 kali dalam mengkonsumsi kopi memiliki rentantang paling banyak karena biasanya memang lelaki paling suka berkumpul dengan teman temennya di luar untuk mengkonsi kopi. Adapun hasil yang dapat dilihat dari diagram pie di bawah ini:

Gambar 3. Diagram Pie Profil Responden Berdasarkan Frekuensi Membeli Kopi dalam 1 Minggu

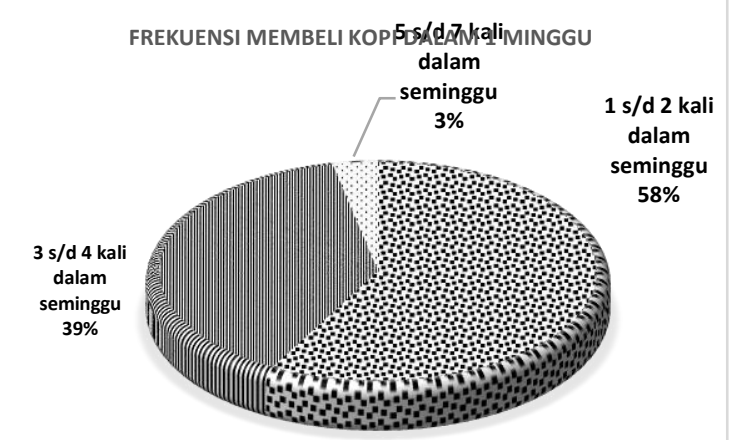

Sumber : Hasil Olah Data Penulis (2021)

b. Frekuensi Berkunjunng Ke Sudut Pandang Kopi

Berdasarkan hasil olah data dari hasil responden yang berkunjung untuk membeli kopi yaitu pengunjung yang sudah pernah berkunjung ke Susut Pandang Kopi sebanyak 150 responden maka dapat disimpulkan bahwa menurut hasil 1-2 kali dalam semingu sebanyak $58 \%$ sedangkan dari hasil konsumsi 3-4 kali dalam seminggu adalah $39 \%$ dan yang terakhir 5-7 kali dalam seminggu $3 \%$. maka dapat simpulkan dimana pada frekuensi 1-2 kali dalam mengkonsumsi kopi memiliki rentantang paling banyak karena biasanya memang lelaki paling suka berkumpul dengan teman temennya di luar untuk mengkonsi kopi. Adapun hasil yang dapat dilihat dari diagram pie di bawah ini:

Gambar 4. Diagram Pie Profil Responden Berdasarkan Frekuensi Berkunjung Ke Sudut Pandang Kopi

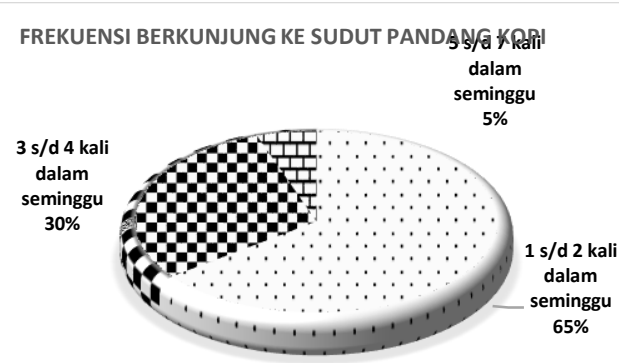

Sumber : Hasil Olah Data Penulis (2021)

c. Mengetahui Informasi Mengenai Sudut Pandang Kopi

Gambar 5. Diagram Pie Profil Responden Berdasarkan Informasi Mengenai Sudut Pandang

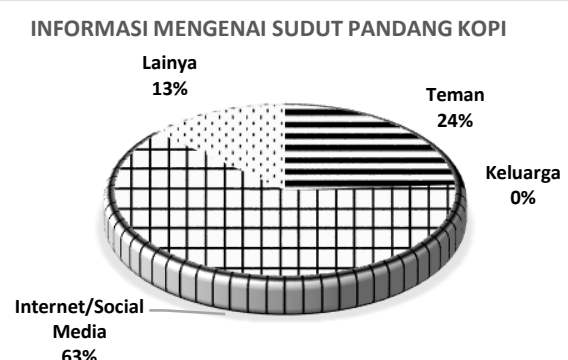

Sumber : Hasil Olah Data Penulis (2021)

Berdasarkan hasil olah data dari hasil responden yang mengetahui informasi sudut pandang kopi yaitu pengunjung yang sudah pernah berkunjung ke Susut Pandang Kopi sebanyak 150 responden maka di atas dapat disimpulkan bahwa menurut hasil mengetahui susut pandang kopi melalui media Internet atau social media sebanyak $63 \%$ sedangkan dari hasil mengetahui susut pandang kopi melalui teman atau rekan adalah 24\%, kemudian mengetahui susut pandang kopi melalui lainya 13\% dimana biasa saja dekat dengan kantor mereka, langsung datang dsb dan sisanya adalah $0 \%$ dari keluarga. . maka dapat simpulkan dimana pada informasi mengenai sudut pandang kopi paling banyak adalah paling banayak melalui social media atau internet memang peran siosial media saat ini sangatlah berpengaruh dalam melakukan promosi yang ada. .

d. Jenis Kelamin

Dari hasil responden berdasarkan jenis kelamin menerangkan bahwa data responden 
berjenis kelamin laki-laki sebanyak 90 (Sembilan puluh ) orang atau $60 \%$ dari total responden dan responden berjenis kelamin perempuan sebanyak 60 (enam puluh ) orang atau $40 \%$ dari total responden. Maka dalam hal ini dapat dikatakan bahwa responden berjenis Laki laki lebih banyak berkunjung ke Sudut Pandang Kopi. Karena laki laki sangat suka sekali minum kopi, dikarenakan kopi sendiri memiliki kadar kafeein yang tinggi dan di butuhkan oleh para lelaki untuk mendampingi pada saat sedang bekerja. Dimana dapat di lihat dari diagram berikut : Gambar 6. Diagram Pie Profil Responden Berdasarkan Jenis Kelamin

JENIS KELAMIN

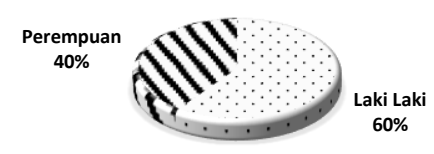

Sumber : Hasil Olah Data Penulis (2021)

e. Usia

Gambar 7. Diagram Pie Profil Responden Berdasarkan Usia

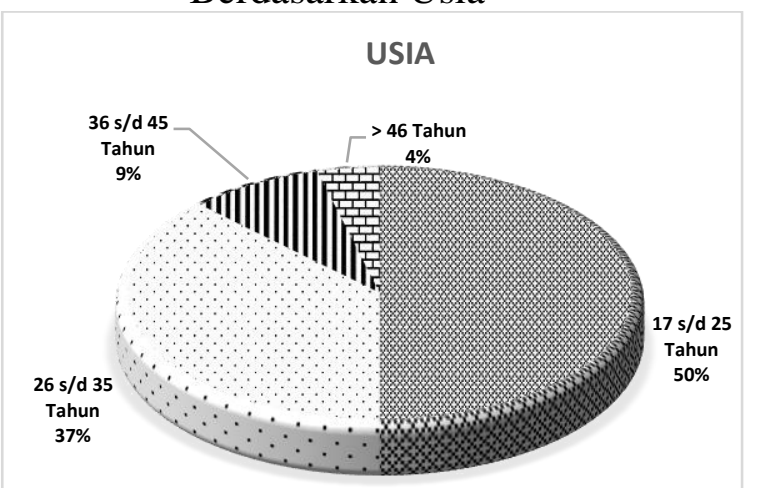

Sumber : Hasil Olah Data Penulis (2021)

Berdasarkan hasil olah data yang di ambil dari responden yaitu pengunjung yang sudah pernah berkunjung ke Susut Pandang Kopi sebanyak 150 responden maka dapat disimpulkan bahwa menurut komposisi usia terdapat sebanyak 75 responden yang berada pada rentang usia 17-25 tahun, 56 responden yang berada pada rentang usia 25-35 tahun, 13 responden yang berada pada rentang usia 35-45 tahun dan 6 responden yang berada pada rentang usia $>46$ tahun. Dimana usia
17-25 tahun memiliki rentantang paling banyak karena usis ini merupakan kategori usia Remaja akhir dimana usia produktif dan masih menghasilkan banyak ide dan suka nongkrong santai dengan rekannya.

\section{f. Pekerjaan Responden}

Berdasarkan hasil olah data dari diagram di bawah yang di ambil dari responden yaitu pengunjung yang sudah pernah berkunjung ke Sudut Pandang Kopi sebanyak 150 responden maka dapat disimpulkan bahwa menurut jenis pekerjaan responden terdapat sebanyak 46 responden yang berstatus sebagai Pelajar atau Mahasiswa, 50 responden dengan pekerjaan sebagai Pegawai Swasta, 26responden dengan pekerjaan sebagai Wirausaha, 28 responden yang berstatus sebagai PNS. Dinama hasil observasi penulis mendapatkan mayoritas pekerjaan dari konsumen sudutpandang kopi merupakan adalah pegawai swasta dimana untuk jenis pekerjaan ini dimulai dari usia 17-46 tahun. Yang menjadi pasar pelanggan sudut pandang kopi selain itu disekitar ara sudut pandang kopi merupakan banyak jenis perkantoran .

\section{Gambar 8. Diagram Pie Profil Responden Berdasarkan Pekerjaan}

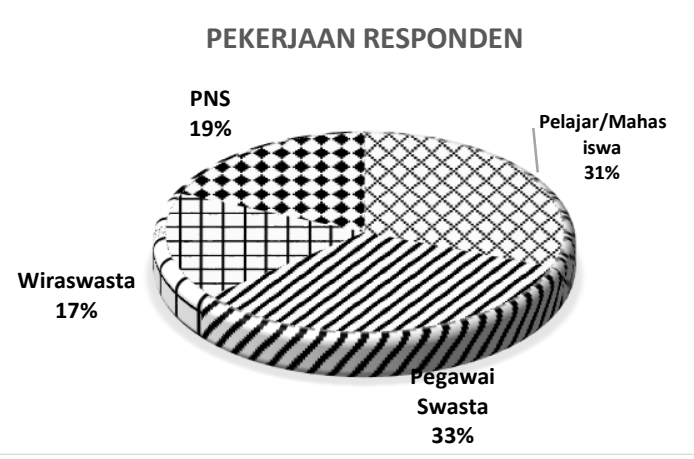

Sumber : Hasil Olah Data Penulis (2021)

\section{g. Pendapatan Bulanan}

Berdasarkan hasil pengolahan data dapat dijelaskan bahwa, Starting pendapatan dimulai dari < Rp.1.500.000 sampai dengan $>$ Rp. 3.500.000. Dimana dari pendapatan ini termasuk dari hasil uang saku maupun dari hasil pendapatan bekerja para konsumen 
sudut pandang kopi. Berikut adalah hasil survey data pendapatan konsumen sudut pandang kopi.

\section{Gambar 9. Diagram Pie Profil Responden Berdasarkan Pendapatan Per Bulan}

PENDAPATAN PER BULAN

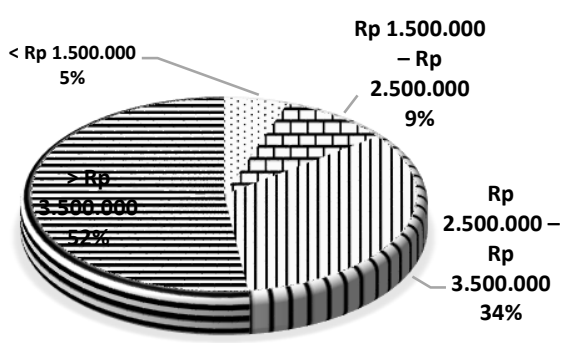

Sumber : Hasil Olah Data Penulis (2021)

Berdasarkan penjelasan yang telah dijabarkan di atas, maka dapat disimpulkan bahwa responden dengan jenis kelamin yang paling dominan adalah laki laki yaitu sebanyak 90 (sembilan puluh) orang atau sebesar $60 \%$ dari total keseluruhan responden. Selanjutnya, responden dengan rentan usia 17-25 tahun adalah 50\% dari total keseluruhan responden, dimana pekerjaan yang ada adalah pegawai swasta . Kemudian terkait dengan domisili, responden yang paling dominan adalah responden yang berdomisili di DKI Jakarta dengan jumlah sebesar $50 \%$ dari total keseluruhan responden, dimana penghasilan yang dominan adalah > Rp. 3.500 .000 dinama standart UMR di DKI Jakarta sebesar Rp. 4.500.000. dan mayoritas konsumen Sudut Pandang Kopi adalah pegawai swasta yang ada disekitar outlet sudut pandnag kopi.

\section{h. Domisili}

Berdasarkan hasil pengolahan data gambar diagram pie di bawah dapat dijelaskan bahwa, responden pada domisili Bali berjumlah 11 orang atau sebesar $7 \%$ dari total keseluruhan responden. Selanjutnya pada domisili Pontianak berjumlah 15 orang atau sebesar $10 \%$ dari total keseluruhan responden. Responden pada domisili Dumai berjumlah 15 orang atau sebesar $10 \%$ dari total keseluruhan responden. Kemudian pada domisili Pekanbaru berjumlah 10 orang atau sebesar 7\% dari total keseluruhan responden. Selanjutnya adalah pada domisili Tangerang berjumlah 24orang atau sebesar $16 \%$ dari total keseluruhan responden yang terakhir adalah domisili DKI Jakarta berjumlah 75 orang atau sebesar $50 \%$ dari total keseluruhan responden. Maka dapat disimpulkan bahwa pengunjung yang lebih banyak melakukan kunjungan wisata ke Sudut Pandang Kopi adalah pengunjung dari masyarakat berdomisili DKI Jakarta sendiri, hal ini dapat terjadi karena konsumen yang mengisi kuisioner adalah warga DKI Jakarta maupun Tangerang dan lokasi terbanyak adalah di 2 wilayah tersebut dan yang lainya bau ada hanya 1 outlet di masing masing wilayah.

\section{Gambar 10. Diagram Pie Profil Responden Berdasarkan Domisili} DOMISILI

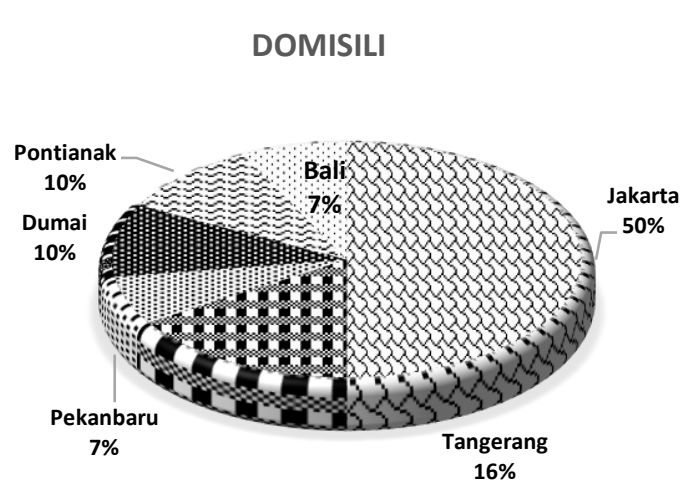

Sumber : Hasil Olah Data Penulis (2021)

Riyanto (2020:137) mengatakan bahwa uji asumsi klasik adalah uji persyaratan yang digunakan untuk uji regresi dengan metode estimasi Ordinal Least Squares (OLS). Uji asumsi klasik pada umumnya ada 4 (empat), yaitu uji normalitas, uji autokorelasi, uji multikolinearitas dan uji heteroskedastisitas.

Berdasarkan hasil pengujian pada tabel diatas, hasil pengujian One Sample Kolmogorov-Smirnov test menghasilkan asymptotic significance $>0,05$ yaitu 0,061 Berdasarkan hasil Penelitian ini, maka dapat disimpulkan bahwa model regresi telah memenuhi asumsi kenormalan. 
Uji multikolinearitas bertujuan untuk melihat ada atau tidaknya korelasi yang tinggi antara variabel-variabel bebas dalam suatu model regresi linear berganda. Jika ada korelasi yang tinggi di antara variabelvariabel bebasnya, maka hubungan antara variable bebas terhadap variabel terikatnya menjadi terganggu. Duli (2019:120). Dasar pengambilan keputusan: Menurut Nikolaus Duli (2019:120) tidak terjadi gejala multikolinearitas, jika nilai Tolerance $>0,10$ dan nilai VIF $<10,00$. Berdasarkan hasil data pada penelitian ini bahwa dalam tahap uji multikolinearitas pada Pembayaran Non Tunai (X1) hasil nilai Tolerance $0.457>0,10$ dan nilai VIF $1.205<10,00$. Selanjutnya pada Promosi (X2) hasil nilai Tolerance $0.457>0,10$ dan nilai VIF $1.205<10,00$. Dapat disimpulkan bahwa tidak ada gejala multikolinearitas.

Singgih Santoso (2019:205) Alat uji ini digunakan untuk mengetahui apakah dalam sebuah model regresi linier ada korelasi antara kesalahan pengganggu pada periode $\mathrm{t}$ dengan kesalahan pada periode $\mathrm{t}-1$ (sebelumnya). Berdasarkan hasil uji pada penelitian ini, pada tabel Durbin Watson, terdapat angka D-W di bawah - 2 sebesar + 0.778 berarti terdapat autokorelasi positif. Maka dapat disimpulkan model regresi di atas tidak terdapat masalah autokorelasi. Hal ini sejalan dengan apa yang dikatakan oleh Singgih Santoso (2019:207) bahwa angka D$\mathrm{W}$ sebesar + 1.156, hal ini berarti model regresi di atas tidak terjadi masalah.

Uji heteroskedastisitas adalah untuk melihat apakah terdapat ketidaksamaan varian dari residual satu pengamatan ke pengamatan yang lain Nikolaus Duli (2019:122). Berdasarkan hasil data pada penelitian ini bahwa dalam tahap uji heteroskedastisitas, kesimpulannya adalah tidak terjadi heteroskedastisitas.

Tabel 4. Hasil Uji Regresi Berganda

\begin{tabular}{|l|c|c|c|c|c|}
\hline \multicolumn{5}{|c|}{ Coefficients $^{\mathbf{a}}$} \\
\hline Model & $\begin{array}{c}\text { Unstandardize } \\
\text { d Coefficients }\end{array}$ & $\begin{array}{c}\text { Standardize } \\
\mathrm{d} \\
\text { Coefficients }\end{array}$ & & & \\
& & & & \\
\cline { 2 - 4 } & B & Std. & Beta & & \\
\hline
\end{tabular}

\begin{tabular}{|l|l|l|l|l|r|r|}
\hline \multicolumn{2}{|l|}{} & & Error & & & \\
\hline 1 & (Constant) & 8.607 & 1.542 & & 5.58 & 0.00 \\
& & & & 2 & 0 \\
\cline { 2 - 7 } & Pembayara & 0.438 & 0.045 & 0.629 & 9.75 & 0.00 \\
n non tunai & & & & 1 & 0 \\
\cline { 2 - 7 } & Media & 0.223 & 0.066 & 0.218 & 3.37 & 0.00 \\
& & & & 5 & 1 \\
\hline & Promosi & & & & 5 \\
\hline
\end{tabular}

Sumber : Hasil Olah data Penulis (2021)

Dari tabel tersebut dapat disimpulkan bahwa hasil perhitungan koefisien regresi sederhana diatas memperlihatkan nilai koefisien konstanta sebesar 8,607 sedangkan nilai koefisien variabel Pembayaran Non Tunai (X1) sebesar 0,438 dan nilai koefisien variabel Promosi (X2) sebesar 0,223.

Nilai - nilai koefisien yang terdapat di tabel Coefficients diatas jika dimasukkan pada persamaan seperti berikut:

$\mathrm{Y}=8,607+0,438 \mathrm{X} 1+0,223 \mathrm{X} 2$

Persamaan regresi diatas dapat dijelaskan sebagai berikut :

1. Hasil perhitungan analisis mengidentifikasikan bahwa nilai a (konstanta) 8,607. Berarti jika tidak ada variabel independen Pembayaran Non Tunai dan Promosi atau nilainya adalah 0 maka minat berkunjung 8,607.

2. $\mathrm{b} 1=$ Koefisien regresi Motivasi $(\mathrm{X} 1)=$ 0,438 , artinya Pembayaran Non Tunai mempunyai hubungan yang positif terhadap keputusan pembelian konsumen, jika variabel Pembayaran Non Tunai meningkat sebesar satu poin, maka akan meningkatkan variabel Keputusan Pembelian sebesar 0,438 dengan asumsi variabel bebas lainnya tetap atau konstan. Menurut hasil analisa penulis hubungan faktor Pembayaran Non Tunai tersebut positif karena Sudut Pandang Kopi sudah menerapkan faktor-faktor tersebut atau sudah sesuai dengan Kebutuhan Konsumen yang sudah pernah berkunjung (sudah merasakannya langsung).

3. $\mathrm{b} 2=$ Koefisien regresi Promosi $(\mathrm{X} 2)=$ 0,223, artinya Promosi mempunyai hubungan yang positif terhadap keputusan Keputusan Pembelian Konsumen, jika variabel Promosi meningkat sebesar satu 
poin, maka akan meningkatkan variabel Keputusan Berkunjung sebesar 0,223 dengan asumsi variabel bebas lainnya tetap atau konstan. Menurut hasil analisa penulis hubungan faktor Promosi tersebut positif karena Sudut Pandang Kopi sudah menerapkan faktor-faktor tersebut atau sudah sesuai dengan keputusan Pembelian Konsumen yang sudah pernah berkunjung (sudah merasakannya langsung).

Tabel 5. Hasil Uji T

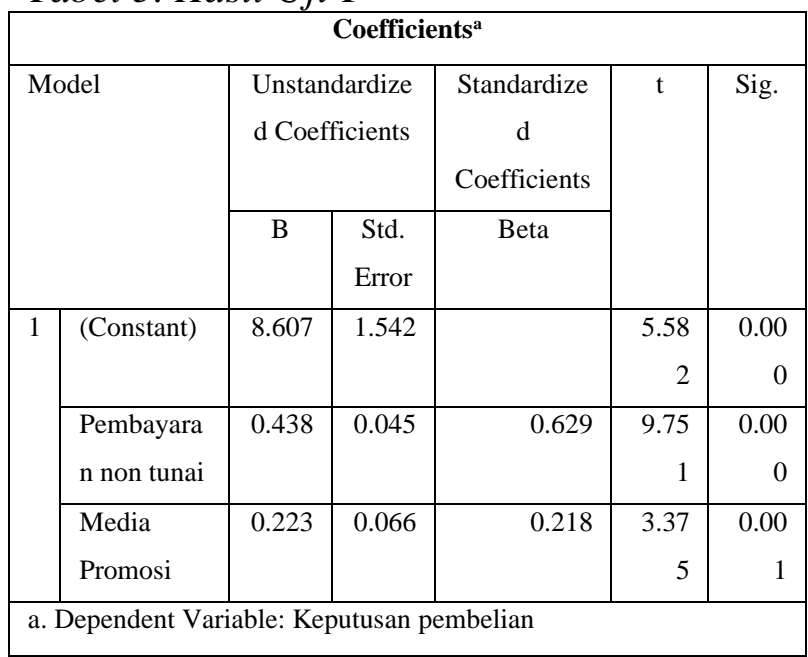

Sumber : Hasil Olah data Penulis (2021)

Hasil Pengujian Hipotesis Pertama (H1), diketahui nilai Sig untuk pengaruh X1 terhadap Y adalah sebesar $0,000<0,05$ dan nilai t hitung 9,751 > t tabel 1,976 sehingga dapat disimpulkan bahwa berdasarkan hasil uji secara parsial H0 ditolak yang berarti terdapat pengaruh Pembayaran Non Tunai (X1) terhadap Keputusan Pembelian (Y) secara signifikan. Berpengaruh secara signifikan dilihat dari hasil analisa penulis, dimana faktor Pembeyaran Non Tunai mempengaruhi keputusan Pembelian untuk membeli Minuman atau makanan yang ada di Sudut Pandang Kopi

Hasil Pengujian Hipotesis Kedua (H2), diketahui nilai Sig untuk pengaruh X2 terhadap Y adalah sebesar $0,000<0,05$ dan nilai t hitung 3,375>t tabel 1,976 sehingga dapat disimpulkan bahwa berdasarkan hasil uji secara parsial H0 ditolak yang berarti terdapat pengaruh Promosi (X2) terhadap Keputusan Pembelian(Y) secara signifikan. Berpengaruh secara signifikan dilihat dari hasil analisa penulis, dimana faktor Promosi yang ada di Sudut Pandang Kopi mempengaruhi keputusan Membeli makanan maupun minuman.

\section{Tabel 6. Hasil Uji F}

\begin{tabular}{|c|c|c|c|c|c|c|}
\hline \multicolumn{7}{|c|}{ ANOVA $^{\mathrm{a}}$} \\
\hline \multicolumn{2}{|c|}{ Model } & Sum of & df & Mean & $\mathrm{F}$ & Sig. \\
\hline \multirow[t]{3}{*}{1} & Regression & 768.812 & 2 & 384.406 & 112.802 & $.000^{\mathrm{b}}$ \\
\hline & Residual & 500.948 & 147 & 3.408 & & \\
\hline & Total & 1269.760 & 149 & & & \\
\hline \multicolumn{7}{|c|}{ a. Dependent Variable: Keputusan pembelian } \\
\hline \multicolumn{7}{|c|}{ b. Predictors: (Constant), Media Promosi, Pembayaran non tunai } \\
\hline \multicolumn{7}{|c|}{ Sumber : Hasil Olah data Penulis (2021) } \\
\hline \multicolumn{7}{|c|}{$\begin{array}{l}\text { berdasarkan output diatas diketahui nilai } \\
\text { signifikansi untuk pengaruh Pembayaran } \\
\text { Non Tunai (X1) dan Promosi (X2) secara } \\
\text { simultan terhadap Keputusan Pembelian (Y) } \\
\text { adalah sebesar } 0,000<0,05 \text { dan } F \text { hitung } \\
112,802>\mathrm{F} \text { tabel } 3,91 \text {, sehingga dapat } \\
\text { disimpulkan bahwa H0 ditolak yang berarti } \\
\text { terdapat pengaruh Pembayaran Non Tunai } \\
\text { (X1) dan Promosi (X2) secara simultan }\end{array}$} \\
\hline
\end{tabular}

\section{Tabel 7. Hasil Uji Koefisien Determinasi} (R2)

\begin{tabular}{|l|c|r|r|c|}
\hline \multicolumn{5}{|c|}{ Model Summary } \\
\hline Model & $\mathrm{R}$ & R Square & $\begin{array}{c}\text { Adjusted R } \\
\text { Square }\end{array}$ & $\begin{array}{c}\text { Std. Error } \\
\text { of the } \\
\text { Estimate }\end{array}$ \\
\hline 1 & $.778^{\mathrm{a}}$ & 0.605 & 0.600 & 1.846 \\
\hline $\begin{array}{l}\text { a. Predictors: (Constant), Media Promosi, Pembayaran non } \\
\text { tunai }\end{array}$ \\
\hline
\end{tabular}

Sumber : Hasil Olah data Penulis (2021)

Dari hasil penelitian yang telah dilakukan, maka didapat hasil Korelasi ( $\mathrm{R}=$ 0,778 mendekati 1 (satu) ), menunjukkan bahwa hubungan atau pengaruh variabel Pembayaran Non Tunai (X1) dan Promosi (X2) terhadap Keputusan Pembelian (Y) mempunyai korelasi kuat.

Sedangkan koefisien determinasi digunakan untuk mengetahui seberapa besar pengaruh variabel Pembayaran Non Tunai 
(X1) dan Promosi (X2) secara simultan terhadap variabel Keputusan Pembelian (Y), dimana memberikan pengaruh variabel $(\mathrm{X})$ sebesar $66,9 \%$ terhadap variabel (Y) dan sisanya sebesar $33,1 \%$ dipengaruhi oleh faktor lain yang tidak diteliti.

\section{KESIMPULAN}

Berdasarkan hasil pengolahan data dan pembahan mengenai pengaruh pembayaran non tunai sebagai promosi pada masa pandemic Covid 19 terhadap keputusan pembelian di Sudut Pandang Kopi yang telah dijelaskan pada bab sebelumnya, maka dapat disimpulkan sebagai berikut :

Berdasarkan hasil pengolahan data dan pembahasan pada penelitian ini, maka dapat disimpulkan bahwa dari hasil penelitian pada uji t parsial (X1) Pembayaran Non Tunai diketahui variabel bebas fasilitas wisata secara parsial memiliki pengaruh signifikan terhadap variabel terikat Keputusan Pembelian. Selanjutnya (X2) Promosi diketahui variabel bebas promosi secara parsial memiliki Berpengaruh secara signifikan dilihat dari hasil analisa penulis, dimana faktor Promosi yang ada di Sudut Pandang Kopi mempengaruhi keputusan Membeli makanan maupun minuman. Hasil uji $F$ dalam penelitian bahwa variable Pembayaran Non Tunai dan promosi sebagai variable bebas secara simultan mempengaruhi Keputusan Pembelian. Hasil uji regresi linear berganda dengan konstanta 8,607 memberikan nilai positif dan memberikan ketepatan prediksi bahwa ada pengaruh yang terjadi antara (X1) Pembayran Non Tunai dan (X2) Promosi terhadap(Y) Keputusan Pembelian pada Sudut Pandang Kopi. Saran penelitian ini adalah . Bagi konsumen yang sudah datang sebanyak 10 kali diberi gift atau voucher agar konsumen mempromosikan secara tidak langsung kepada rekan-rekannya untuk datang berkunjung. Dalam hal promosi karena yang berdampak besar melalui sosial media lebih baik mengundang selebgram yang sangat berpengaruh kepada dunia sosial media, agar yang berkunjung semakin ramai.

\section{DAFTAR PUSTAKA}

Depkes RI (2009). Klasifikasi Umur Menurut Kategori.jakarta : Ditjen Yankes

Duli, N. (2019). Metodologi Penelitian Kuantitatif: Beberapa Konsep Dasar untuk Penulisan Skrisi \& Analisis Data dengan SPSS. Sleman. Yogyakarta: PENERBIT DEEPUBLISH (Grup Penerbitan CV BUDI UTAMA).

Hair, Joseph F. Jr. et al. 2010, Multivariate data analiisis $7^{\text {th }}$ Edition, Pearson. Education Limited. Harlow. England http://www.kemenperin.go.id/artikel/18384/ Tumbuh-9,46-Persen,-IndustriMamin-Kontributor-Terbesar-PDBManufaktur, Terhubung Berkala, Akses pada tanggal 18 desember 2020

Riyanto, Slamet.,\& Hatmawan, A. (2020). Metode Riset Penelitian Kuantitatif Penelitian di Bidang Manajemen, Teknik, Pendidikan dan Eksperimen. Sleman. Yogyakarta:PENERBIT DEEPUBLISH (Grup Penerbitan CV Budi Utama).

Santoso, S. (2019). Mahir Statistik Parametrik (Konsep Dasar dan Aplikasi Dengan SPSS). Jakarta: PT. Elex Media Komputindo.

Siregar, Syofian. 2015. Metode Penelitian kuantitatif dilengkapi dengan Perbandingan Perhitungan Manual \& SPSS. Jakarta : Kencana Prenada Media Group.

Sugiyono. (2017). Metodologi Penelitian Kuantitatif, Kualitatif, dan R\&D. Bandung: Alfabeta. 